\title{
Demand for Money in Sri Lanka During the Post Liberalisation Period
}

\author{
W R A Dharmaratne ${ }^{1}$
}

\begin{abstract}
This paper investigates the long run demand for money and the short run dynamics of the long run money demand. The estimation of a money demand function for $M_{1}$, using quarterly data for 1978 Q1 to 2003 Q4 forms the basis of this investigation. The findings of the study reveal that $M_{1}$ is co-integrated with real income and the nominal interest rate. The study, further found that the one year term-deposit rate of commercial banks was the best fit for the model used when compared to alternative interest rates such as the 3-month Treasury bill rate, the 12- month Treasury bill rate and the repo rate, implying that the 1-year term deposit rate is the opportunity cost of holding money. We also found that $M_{2}$ is not co-integrated with real income or any of the above interest rates, in nominal terms. This indicates that monetary authorities should pay close attention to the narrow definition of money when formulating monetary policy. (JEL E41, E47)
\end{abstract}

\section{Introduction}

To adopt an effective monetary policy, it is essential to understand the characteristics of money market, particularly the money demand function. In the absence of reliable estimates of money demand function, an optimal monetary policy cannot be formulated. Formulating a sound monetary policy requires a clear understanding of what monetary aggregate the monetary authority should control and what factors affect the demand for money. Although numerous studies exist on demand for money in developed countries, much less effort has been made to understand money demand relationships in developing countries. This paper investigates the long run demand for money and short-run dynamics associated with the long-run money demand function for Sri Lanka during the post liberalisation period and reports on the estimates of a money demand function for Sri Lanka. These estimates are essential for the formulation of monetary policy and forecasting inflation. We report the

\footnotetext{
1/ Author wishes to acknowledge the contributions made by Mr. C Amarasekara, Miss. A S De Alwis, Mr. B D W A Silva, Mr. A A M Thasim, Mrs. S K Rupasingha and Miss S M Wimalasooriya for the preparation of this paper. The author also wishes to express his sincere thanks to Prof. William A.Branson for his valuable comments and suggestions for finalising the paper. Author is also solely responsible for any errors and for the views expressed in the paper.
} 
short-run and long-run elasticities using the Koyck lag specification. Further, tests were carried out using several alternative interest rates to determine the best proxy for opportunity cost of holding money.

The post liberalisation period was selected for this study as market economy conditions did not prevail in the country during much of the period before 1977. In 1977, the newly elected government took steps to liberalise the trade and financial sectors of the economy. With respect to trade, quantitative restrictions on import trade were removed and price controls were phased out. Incentive schemes were introduced to encourage foreign direct investment. Even though the capital account was not fully liberalised restrictions on some capital transactions were gradually lifted. Meanwhile, greater coordination was established among monetary policy, fiscal policy and exchange rate policy. In keeping with these changes in the macro economic policy framework the Central Bank of Sri Lanka (CBSL) has also moved away from direct controls to market based tools in implementing monetary policy. Accordingly, administratively determined interest rates were gradually abandoned and credit controls were also gradually eliminated.

In November 1977, the dual exchange rate system was abolished by establishing a unified exchange rate to ensure the long-run viability of the balance of payments in a market oriented economic environment. A large depreciation of the rupee in 1978 (85 per cent) resulted in a sharp increase in the inflow of worker remittances into the country and this resulted in a large increase in monetary aggregates in the country. Narrow money $\left(M_{1}\right)$ recorded a large increase of 29 per cent at end 1979 in comparison to an increase of 11 per cent at end 1978 while broad money $\left(\mathrm{M}_{2}\right)$ grew by 37 per cent and 24 per cent respectively during the same periods. Considerable changes have also taken place in the deposit rates and Treasury bills rates. Between 1978 and 2003, the rupee was devalued by 524 per cent against the US dollar. Meanwhile, real narrow money increased by 87 per cent during the period 1978-2003. The average annual growth in real GDP during the last two decades was around 4.3 per cent and 4.5 per cent respectively.

Considerable developments have been recorded in the financial sector along with the liberalisation policies implemented in 1977. Amendments were made to various Acts such as the Monetary Law Act, the Banking Act and the Finance Companies Act, to facilitate and further strengthen the activities in the financial sector. Market rates were allowed to be determined according to the market demand and supply factors. Accordingly, a significant variability in domestic interest rates can be seen during the selected sample period for the study. With the implementation of the active open market operations system in March 2003, however, particularly short term interest rates have stabilised significantly.

There have been previous studies of the money demand function for Sri Lanka. However, the significant developments during the last several years, such as the floating of the exchange rate and the implementation of the active market operations system, warrant a fresh study of the demand for money in Sri Lanka.

One important criterion for selecting variables is the need for estimating the opportunity cost of holding money. In this respect, there exist various deposit rates such as the 1-year fixed deposit rate, the 6-month fixed deposit rate, the 3-month fixed deposit rate and the 1year savings deposit rate of the National Savings Bank which are important in the system. 
We do not know which interest rate is the best proxy for the opportunity cost of holding money. Therefore, we need to examine the alternative interest rates to identify the best proxy for the opportunity cost of holding money.

In addition to these variables, some argue that the depreciation of the domestic currency also influence the demand for money (Arango and Nadiri,1981). The depreciation of the domestic currency may increase the demand for foreign securities by domestic residents, thereby increasing the demand for domestic currency. On the other hand, Simmons (1992) argues that the effect of the transfer of assets from domestic assets to foreign assets (substitution effect due to the interest rate differentials of domestic and foreign interest rates) also need to be considered when specifying the demand for holding money in open economies. However, in the case of Sri Lanka, the liberalisation of the capital account was undertaken gradually and it is not fully liberalised. Therefore, the inclusion of such variables will not influence the demand for money significantly.

The rest of the paper is structured as follows. Section II provides a survey of literature, which includes empirical work on the money demand function in respect of other countries. In Section III the methodology is developed for the estimation of money demand function and a description of the data used for estimation is also presented. The estimation procedure is discussed in Section IV. In Section V, the empirical findings are discussed. According to the results of the study, real money balances $\left(\mathrm{M}_{1}\right)$ is co-integrated with real income and the one-year term deposit rate and $\mathrm{M}_{2}$, which is a broader measure of money is not. As anticipated, the evidence suggests that there exists a long run equilibrium relationship between real $\mathrm{M}_{1}$ and real GDP and the one year fixed deposit rate for the post liberalisation period. The $M_{1}$ monetary aggregate is seen to be more sensitive to changes in the one year fixed deposit rate than to changes in other interest rates i.e., yield on Treasury bill or the repo rate. Therefore, commercial bank's one year fixed deposit rate is a significant determinant which has been considered in this study as the opportunity cost of holding money. This indicates that the one year fixed deposit rate best represents the opportunity cost of holding money in the long-run. The point estimate of the long run income elasticity is significant, which is greater than zero but smaller than unity. Further, the value of the speed of adjustment coefficient is satisfactory but the value is low in comparison to developed countries. Concluding remarks are given in Section VI.

\section{Existing Literature and Selection of Variables}

The money demand function is widely examined in empirical research. However, only a few studies have been done in respect of estimating the money demand function for Sri Lanka. One such study on the subject was done by Weliwita and Ekanayake (1998). In this study, it was found that $\mathrm{M}_{1}$ is co-integrated with real income, nominal interest rate, shortterm foreign interest rate and real effective interest rate. The one year fixed deposit rate is cointegrated with $\mathrm{M}_{1}$, indicating the opportunity cost of holding money. 


\section{A. Money Stock}

The money stock is mainly classified into two groups i.e., narrow money and broad money. Narrow money consists of those assets that are readily available for transactions while broad money encompasses a wider range of assets. Several definitions of money have been used in various studies. The correct definition of money is an empirical matter. Several measures of money can be used according to the objective of the users (Sriram, 1999). In this paper, narrow money $\left(\mathrm{M}_{1}\right)$ stock is used as the dependent variable; it is measured as a quarterly average of monthly data and deflated by the CCPI.

\section{B. Scale Variable}

The scale variable is used to measure the transactions relating to economic activity. The most commonly used variables are GDP (Gross Domestic Product) or GNP (Gross National Product). In some studies, wealth also has been used as a scale variable. This paper uses real GDP as a proxy for the scale variable. However, it was required to interpolate the annual series on real GDP to obtain quarterly series since quarterly data are not available for the entire period under review. To obtain these quarterly data the procedure outlined and used in Goldstein and Khan (1976) was applied. In some other studies (Arize, 1994) also this method has been used in order to achieve the desired results.

\section{Opportunity Cost Variables}

The importance of interest rates in money demand has been firmly established by research. However, there is no consenses as to which interest rate should be used as the opportunity cost of holding money i.e. short-term or long-term.

In some early studies, the inflation rate has been used as a proxy for the opportunity cost of holding money when examining the demand for money while some have used a shortterm market rate such as the Treasury bill rate or the commercial paper rate. Laurence Ball (2002) has used the rate of return on near monies as the opportunity cost of holding money. Near monies are defined as the non- $\mathrm{M}_{1}$ component of $\mathrm{M}_{2}$, except time deposits. These assets are considered as close substitutes for $\mathrm{M}_{1}$ because they are highly liquid. Accordingly, the average return on savings accounts has been considered as the opportunity cost of holding money in his study.

Some researchers argue that most of the people in developing countries at a live near subsistence level and hold money for precautionary purposes over the short-run. This reveals that the short-term interest rate is more appropriate as the opportunity cost of holding money. Some state that domestic interest rates should not be taken as a proxy for the opportunity cost of holding money as these rates are arbitrarily determined by regulatory authorities in most of the developing countries instead of being set by market demand and supply forces.

However, along with the financial sector development during the post liberalisation period (post 1970s), many developing countries have witnessed the removal of various restrictions in the financial sector. This has led to significant improvements in the activities of the banking sector in Sri lanka. Considering these improvements, the one-year term deposit rate was used as a proxy for the opportunity cost of holding money in this study. 


\section{Methodology, Model Specification and Data}

The conventional money demand function has received extensive theoretical and empirical treatment in the literature, not only in developed countries but also in developing countries. These studies have been based on the theories of money demand i.e., Classical theories, Keynesian theories and Post-Keynesian theories. Keynes postulated three motives for holding money: transactions, precautionary and speculative purposes. The money demand function was then represented as $m^{d}=f(y, i)$ where the demand for real balances $\left(m^{d}=M / P\right)$ is a function of real income and nominal interest rate $(i)$.

Desired money holding, say $\mathrm{m}^{*}$ is specified as,

$$
m^{*}=f(r, y)
$$

The actual money holding is assumed to adjust proportionately to the gap between the desired holdings and the last period's holdings, that is,

$$
\begin{aligned}
& m_{t}-m_{t-1}=\gamma\left(m_{t}^{*}-m_{t-1}\right) \\
& o r \\
& \ln m_{t}-\ln m_{t-1}=\gamma\left(\ln m_{t}^{*}-\ln m_{t-1}\right)
\end{aligned}
$$

where $r$ is the coefficient of adjustment. If the desired money holding depends upon real income and the opportunity cost of holding money (1) is specified,

$$
\begin{aligned}
& \ln m^{*}=\beta_{0}+\beta_{1} \ln G D P+\beta_{2} D I \\
& \text { or } \\
& \ln m^{*}=\beta_{0}+\beta_{1} \ln G D P+\beta_{2} \ln D I
\end{aligned}
$$

Substituting (4) or (5) into (2) or (3) the full conventional money demand function is given as,

$$
\begin{aligned}
& \ln m=\beta_{0}+\beta_{1} \ln G D P+\beta_{2} D I+\beta_{3} \ln m_{t-1}+\varepsilon_{t} \\
& \text { or } \\
& \ln m=\beta_{0}+\beta_{1} \ln G D P+\beta_{2} \ln D I+\beta_{3} \ln m_{t-1}+\varepsilon_{t} \\
& \quad \beta_{1}>0, \beta_{2}<0 \text { and } \beta_{3}, 0 .
\end{aligned}
$$

Where $m$ is desired real money balances (here we take narrow money $\mathrm{m}_{1}$ as real money balances), GDP is real gross domestic product, which is a scale variable, DI is domestic interest rate and $e_{t}$ is the econometric error term. The domestic interest rate is used in two different forms i.e. with $\log$ and without $\log$.

\section{A. Velocity and Interest Rates, 1978-2003}

Examining the behaviour of the velocity of $\mathrm{M}_{1}$ and alternative interest rates may help to build up an intuition about the short run behaviour of the money demand function. Figure 1 presents quarterly data on the velocity of $\mathrm{M}_{1}$, the return on near monies ( 1 year fixed deposit rate and the three month Treasury bill rate). Velocity followed an upward trend with fluctuations while the one year fixed deposit rate followed a downward trend with fluctuations. This indicates a negative correlation between these two variables. However, when we take the first differences of both variables, there is a positive correlation between the two variables with a better correlation after the 1990s. Therefore, the return on one year fixed deposits can 
Figure 1
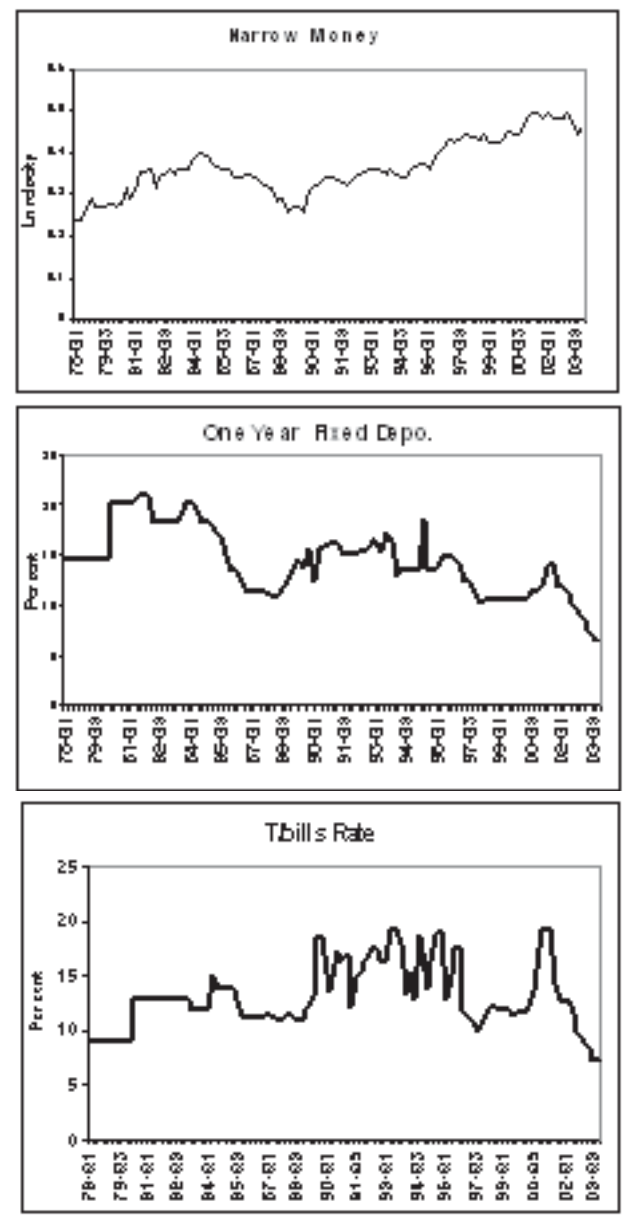

explain the behaviour of velocity during the post liberalisation period. The fluctuations of the fixed deposit rate match the behaviour of velocity. Thus, the increase in the volatility of velocity can be explained by increased volatility in the interest rate

\section{B. Data}

Quarterly data for the period from 1978:Q1 to 2003:Q3 were used for estimation in the study. The post liberalisation period was selected for the study primarily because there were administrative controls on interest rates which were in place before the liberalisation period. The narrow money stock $M_{1}$ (currency plus demand deposits) is used as the dependent variable and it is measured as a quarterly average of monthly data and deflated by the Colombo Consumer's Price Index (CCPI, 1952=100) to obtain real $\mathbf{M}_{1}$. Data on $\mathbf{M}_{1}$ was seasonally 
adjusted to normalise the seasonal fluctuations. Meanwhile, quarterly data for GDP was taken by interpolating annual data series applying the procedure outlined and used in Goldstein and Khan (1976), since the published quarterly data are not available in this regard. The procedure applied for this is given in the appendix. Data on $\mathrm{M}_{1}, \mathrm{M}_{2}$, GDP, CCPI, FD rate (FD rate is the one-year fixed deposit rate of commercial banks), and other alternative interest rates were taken from various issues of annual reports of the Central Bank.

\section{Estimating the money demand function}

The narrow money stock (currency plus demand deposits, $\mathbf{M}_{1}$ ) is used as the dependent variable (m); it is measured as a quarterly average of monthly data and adjusted for real money by using The Colombo Consumer's Price Index (CCPI). Real GDP is defined as income $(y)$ and the interest rate is measured by the rate on one year fixed deposits $(f d)$. The results obtained with ordinary least squares are given below. (The numbers in parenthesis are tstatistics). The opportunity cost of holding money is estimated in two different forms without $\log$ and with $\log$. These equations are given below, i.e., equations (6) and (7)

$\ln m=0.803+0.058 \ln y-0.004 f d+0.825 \ln m_{t-1}+\varepsilon_{t}$

$$
\text { (2.9) (2.1) (2.45) (16.2) }
$$

$\mathrm{R}^{2}=0.95 ;$ standard error $=0.018 ;$ Durbin-Watson statistic $=2.34$.

Sample period $=1978: 1$ to $2003: 4$.

$\ln m=0.816_{+} 0.051 \ln y-0.055 \ln f d+0.843 \ln m_{t-1}+\varepsilon_{t}$
$(2.9)$
(1.8)
(2.4)
(17.1)

$\mathrm{R}^{2}=0.95 ;$ standard error $=0.018 ;$ Durbin-Wotson statistic $=2.37$.

Sample period $=1978: 1$ to $2003: 4$.

The results of these equations seem to be reasonable. The one year fixed deposit rate in equation (6) is significant with the expected sign, with a long run semi elasticity of 0.02 . This implies that if the fixed deposit rate changes, say for example, from 7 per cent to 8 per cent, it reduces money demand by 0.004 per cent in the short run, while in the long-run it reduces money demand by 0.02 per cent. The coefficient of the speed of adjustment, i.e. $r$ in equation (3) is 0.18 (1-0.82). This indicates that the speed of adjustment is slow but it is more plausible than $0-10$ percent estimates that some researches have found. ${ }^{2 /}$ The point estimate of the long-run income elasticity of 0.33 is greater than zero but smaller than unity and also it is significant within the 95 per cent confidence interval. However, the value of the speed of

2/ See for example, the logarithmic specification in Franco Modigliani, Robert Rasche, and Philip Cooper, "Central Bank Policy, the Money Supply, and the Short-term Rate of Interest," Journal of Money, Credit and Banking, vol. 2 (May 1970), pp. 166-218. 
adjustment coefficient is slightly low in comparison to the estimates found for developed countries. ${ }^{3 /}$ In the case of Sri Lanka this may be true since our country falls into the lowincome category and most of the people do not have surplus income or sufficient liquid assets to transfer from one asset to another as in developed countries. Savings are low in these countries and hence it will take time for the GDP to adjust from the disequilibrium path to the equilibrium path. On the other hand, the people who are holding sufficient liquid assets are also not in a position to take timely decisions to transfer assets from one asset to another due to constraints arising from the asymmetric information in the system.

\section{Empirical Findings}

According to the results given in equation (7), the short-run interest elasticity is 0.05 per cent while the long-run interest elasticity is given as 0.34 . The coefficient of the speed of adjustment, i.e. $\gamma$ in equation (3) is $0.16(1-0.84)$. The short-run income elasticity is 0.05 while the long-run income elasticity is 0.32 .

The income elasticity of 0.32 for $\mathrm{M}_{1}$ is similar but slightly lower than the estimates reported in some recent studies including the earlier studies done for Sri Lanka (e.g. 0.43 for Sri Lanka; (Weliwita and Ekanayake, 1998); 0.50 for Korea (Arize, 1994); 0.61 for Sudan (Domowitz and Elbadawi, 1987); 0.53 for USA (Laurence Ball, 2002); and 0.68 for USA (Goldfeld, 1973).

Further, we tested alternative interest rates such as the 6 months Treasury bill rate, the 12 months Treasury bill rate and the repurchase rate in order to observe the behaviour of the money demand function. The results obtained for these alternative interest rates are given in the table 1 .

The results in table 1 gives several important findings of the study. The $M_{1}$ monetary aggregate is shown to be the best fit to changes in the one-year term deposit rate, when compared to other interest rates. The one-year term deposit rate and three months Treasury bill rate were included separately in the equation and tested for the period 1978: Q1 to 2003:Q4. When we include the one-year term deposit rate in the equation correct signs were observed for both real income and the interest rate, which were also significant at the 95 per cent level. Further, when we included the three month Treasury bill rate in the equation, the signs given for both variables were correct but the Treasury bill rate was not significant. We tested the equation including other alternative interest rates viz., the 6-month and 12-month Treasury bill rates and the repurchase rate for the period 1993:Q4 to 2003:Q2. The results obtained show that all interest rates, viz., 6-month and 12-month Treasury bill rates had the correct signs and were significant at ther 90 per cent level while the repurchase rate was significant at the 95 per cent level. However, the estimated sign for real income was incorrect. Therefore, further research studies could be conducted in this regard.

Further, we tested the behaviour of the market determined interest rates along with the changes in policy rates. Simple regressions (ordinary least square) provide evidence that the changes in policy rates are transmitted quickly throughout all maturities. However, transmissions are quicker with shorter maturities than the longer maturities.

3/ See for example, Goldfeld, Stephen M., "The Demand for Money Revised," Brooking Papers on Economic Activity 3 (1973), 577-638. 
Table 1 - Results obtained for alternative interest rates

\begin{tabular}{|c|c|c|c|c|c|}
\hline & In realm & In realm & In realm 1 & In realm ${ }_{1}$ & In realm \\
\hline Constant & $\begin{array}{l}0.803 \\
(0.273)^{*}\end{array}$ & $\begin{array}{l}0.232 \\
(0.182)\end{array}$ & $\begin{array}{l}3.479 \\
(1.30)^{*}\end{array}$ & $\begin{array}{l}3.455 \\
(1.312)^{*}\end{array}$ & $\begin{array}{l}2.945 \\
(1.247)^{*}\end{array}$ \\
\hline In real GDP & $\begin{array}{l}0.058 \\
(0.028)^{*}\end{array}$ & $\begin{array}{l}0.055^{*} \\
(0.027)^{*}\end{array}$ & $\begin{array}{l}-0.049 \\
(0.072)\end{array}$ & $\begin{array}{l}-0.045 \\
(0.073)\end{array}$ & $\begin{array}{l}-0.017 \\
(0.064)\end{array}$ \\
\hline In realm $1(-1)$ & $\begin{array}{l}0.825 \\
(0.051)^{*}\end{array}$ & $\begin{array}{l}0.895 \\
(0.049)^{*}\end{array}$ & $\begin{array}{l}0.663 \\
(0.130)^{*}\end{array}$ & $\begin{array}{l}0.660^{*} \\
(0.131)\end{array}$ & $\begin{array}{l}0.678 \\
(0.130)^{*}\end{array}$ \\
\hline 1 year fixed deposit rate & $\begin{array}{l}-0.004 \\
(0.002)^{*}\end{array}$ & & & & \\
\hline 3 months Treasury bill rate & & $\begin{array}{l}-0.002 \\
(0.001)\end{array}$ & & & \\
\hline 6 months Treasury bill rate & & & $\begin{array}{l}-0.005 \\
(0.003)^{\star \star}\end{array}$ & & \\
\hline 12 months Treasury bill rate & & & & $\begin{array}{l}-0.005 \\
(0.003)^{\star *}\end{array}$ & \\
\hline Repurchase rate & & & & & $\begin{array}{l}-0.005 \\
(0.002)^{*}\end{array}$ \\
\hline $\mathrm{R}^{2}$ & 0.9489 & 0.9537 & 0.4367 & 0.4289 & 0.4469 \\
\hline Durbin Watson Statistic & 2.3415 & 2.4125 & 2.2285 & 2.2526 & 2.1436 \\
\hline
\end{tabular}

Note: Figures are parentheses are standard errors. * indicates statistical significant at the $95 \%$ level. ** indicates statistical significant at the $90 \%$ level.

$\Delta$ tbill3 $=0.80 \Delta$ repo $+0.10 \Delta$ repo $(-1)$

$$
\text { (0.06) (0.06) }
$$

$\Delta$ tbill12 $=0.63 \Delta$ repo $+0.13 \Delta$ repo $(-1)$

$$
(0.07) \quad(0.06)
$$

$\Delta$ fdrate $=0.10 \Delta$ repo $+0.12 \Delta$ repo $(-1)$

$$
\text { (0.06) (0.06) }
$$

One cannot reject the hypothesis that the changes in policy rates will fully pass through within one quarter in the case of 3 month Treasury bill rate. However, the changes in policy rates will not pass quickly, in the case of the one-year term deposit rate as in the case of the Treasury bill rate. ${ }^{4 /}$

4/ A stands for the changes in the corresponding interest rate, thus repo referring to the overnight repo rate; tbill3 refers to the 3 months Treasury bill rate and tbill12 refers to the 12 months Treasury bill rate; and fdrate is the one year term deposit rate of commercial banks.

The standard deviations of the coefficient estimates are show in parentheses 


\section{Inflation Forecasting with money Demand Function}

The long-run money demand from equation (7) gives us:

$$
d m-d p=0.34 \Delta f d+0.32 d y
$$

Therefore,

$$
d p=d m-0.34 \Delta f d-0.32 d y
$$

To forecast, we need $d m, \Delta f d$, and $d y$. With given monetary policy, assume that $\Delta f d=0$. Then

$$
d p=d m-0.32 d y
$$

If the monetary programme includes an assumption about dy (i.e., growth rate @ 5.5\%), then equation (10) can be used to forecast inflation $(d p)$, given the growth rate in $\mathbf{M}_{1}(d m)$, or the growth rate in $\mathrm{M}_{1}$ consistent with any assumed inflation rate.

\section{Concluding Remarks}

We have examined in this paper the long-run demand for money and the short-run dynamics in Sri Lanka during the post liberalisation period. Elasticities of long-run money demand were obtained by employing Koyck's specification. According to the estimated results, the signs of all regression coefficients are consistent with economic theory and major variables are statistically significant. The positive elasticity of money demand in respect of income reveals that money demand for transaction purposes increases when income increases while the negative semi-elasticity relationship between money demand and the interest rate implies that demand for money declines when interest rates increase. The low value of the speed of adjustment coefficient is satisfactory but slightly lower in comparison to the estimates of the developed countries. Low value of the coefficient implies that it will take time for money demand to adjust from the disequilibrium path to the equilibrium path. The $M_{1}$ monetary aggregate is shown to be the best fit for changes in the one-year term deposit rate when compared to changes in other three interest rates. This indicates that one year fixed deposit rate best represents the opportunity cost of holding money in the longrun. The findings of the study imply that the real money balances $\left(\mathrm{M}_{1}\right)$ is co-integrated with real income and the one-year term deposit rate, and $\mathrm{M}_{2}$ is not. This suggests that narrow money $\left(\mathrm{M}_{1}\right)$ is important in respect of monetary policy formulation in Sri Lanka for monetary control. 


\section{References}

Arango, M. and Nadiri M. (1981), "Demand for Money in Open Economies", Journal of Monetary Economics, 7(1), 69-83.

Arize, A. C. (1994), “ A Re-examination of the Demand for Money in Small Developing Countries”, Applied Economics, 26(3), 217-228.

Ball, Laurence, (2002), "Short Run Money Demand”, Mimeo.

Domowitz, I. and Elbadawi, I. (1987), “An Error Correction Approach to Money DemandThe Case of Sudan”, Journal of Development Economics, 26(2), 257-275.

Goldfeld, M. (1973), “The Demand for Money Revised”, Brookings Papers on Economic Activity.

Goldstein, M. and Khan, M.S. (1976), "Large Versus Small Price Changes in the Demand for Imports", IMF Staff Papers, 23,200-225.

Simmons, R. (1992), “An Error Correction Approach to Demand for Money in five African Developing Countries”, Journal of Economics Studies, 19(1), 29-47.

Sriram, S. (1999), "Survey of literature on Demand for Money, Theoretical and Empirical Work with Special Reference to Error Correction Models", IMF Working Papers, WP/99/64.

Weliwita,A. and Ekanayake E. M., (1998), "Demand for Money in Sri Lanka during the post1977 period; a co integration and error correction analysis", Applied Economics, 30, 1219-1229. 


\section{Appendix}

Interpolation method is used to derive the quarterly Gross Domestic Product (GDP) data from annual data, as outlined by Goldstein and Khan (1976). The method can be explained as follows.

Suppose $\mathrm{x}_{\mathrm{t}-1}, \mathrm{x}_{\mathrm{t}}, \mathrm{x}_{\mathrm{t}+1}$ are three successive annual observations of variable $\mathrm{x}$. If the quadratic function that passes through these three successive points is such that:

$$
\begin{aligned}
& \int_{0}^{1}\left(a r^{2}+b r+c\right) d r=x_{t-1} \\
& \int_{1}^{2}\left(a r^{2}+b r+c\right) d r=x_{t} \\
& \int_{2}^{3}\left(a r^{2}+b r+c\right) d r=x_{t+1}
\end{aligned}
$$

Now, integrating, substituting and solving equations for $\mathrm{a}, \mathrm{b}$ and $\mathrm{c}$ gives

$$
\begin{aligned}
& a=0.5 x_{t-1}-x_{t}+0.5 x_{t-1} \\
& b=-2 x_{t-1}+3 x_{t}-x_{t+1} \\
& c=1.8333 x_{t-1}-1.1666 \quad x_{t}+0.333 x_{t+1}
\end{aligned}
$$

Then the four quarterly data within a given year can be interpolated respectively, by using

$$
\begin{aligned}
& \int_{1}^{1.25}\left(a r^{2}+b r+c\right) d r=0.05468 x_{t-1}+0.23438 x_{t}-0.039067 x_{t+1} \\
& \int_{1.25}^{1.50}\left(\mathrm{ar}^{2}+\mathrm{br}+\mathrm{c}\right) \mathrm{dr}=0.00781 \mathrm{x}_{\mathrm{t}-1}+0.26563 \mathrm{x}_{\mathrm{t}}-0.02344 \mathrm{x}_{\mathrm{t}+1} \\
& \int_{1.50}^{1.75}\left(a r^{2}+b r+c\right) d r=-0.02344 x_{t-1}+0.26562 x_{t}+0.00781 x_{t+1} \\
& \int_{1.75}^{2.00}\left(a r^{2}+b r+c\right) d r=-0.0391 x_{t-1}+0.23437 x_{t}+0.05469 x_{t+1}
\end{aligned}
$$

The interpolated series can be expressed at annual rates by multiplying by four. 